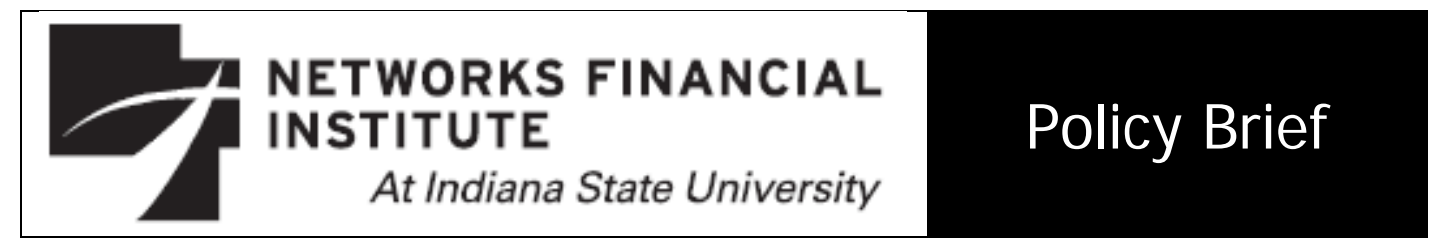

2017-PB-01

March 2017

\title{
Financial Regulation in the Era of Donald Trump
}

\section{R. Christopher Whalen}

Abstract: In the aftermath of the 2008 financial crisis, the focus of politicians in both parties was to punish banks and other financial services companies for a variety of offenses, real and imagined. In many respects, the provisions of the Dodd-Frank law were designed to chastise banks and other companies for perceived wrong doing, especially abuses of consumers. How will the Administration of Donald Trump deal with this legacy and the broader questions of financial regulation? How does regulation rank on the larger list of priorities that includes tax reform, trade, health care and immigration, to name but a few major policy areas.

About the Author: Christopher Whalen is Chairman of Whalen Global Advisors LLC. He is an investment banker and author who lives in New York City. He is a member of the Economic Advisory Committee of the Financial Industry Regulatory Authority (FINRA). Christopher is a member of the National Association of Business Economists. $\mathrm{He}$ is a member of Professional Risk Managers International Association and was regional director of PRMIA's Washington DC chapter (2006-2010). Christopher is a member of the Association for Private Enterprise Education (APEE). He holds Series 79 $\& 24$ securities licenses.

Keywords: Dodd-Frank Act; financial regulation; reform.

J EL classification: K22, K23, P11, P41

The views expressed are those of the individual author and do not necessarily reflect official positions of Networks Financial Institute. Please address questions regarding content to R. Christopher Whalen at chris@rcwhalen.com. Any errors or omissions are the responsibility of the author.

NFI working papers and other publications are available on NFI's website (www.networksfinancialinstitute.org). Click "Research" and then "Publications/Papers." 
Financial Regulation in the Era of Donald Trump

Networks Financial Institute

Indiana State University

By Chris Whalen

March 2017

The November 2016 election and the fact of Republican control of the White House and Congress has caused a number of observers to speculate as to the likely changes in the financial regulatory environment that has evolved since the 2008 financial crisis. The financial markets collapse in that year was caused by a variety of factors that included public policy decisions to encourage home ownership, the proliferation of opaque derivatives, and changes to accounting rules that encouraged acts of securities fraud and other financial misdeeds. ${ }^{1}$

With the passage of the 2010 Dodd-Frank law and many thousands of pages of regulations and legal undertakings that followed, the US financial sector is under greater constraint than at any time since the Great Depression.

In the aftermath of the 2008 financial crisis, the focus of politicians in both parties was to punish banks and other financial services companies for a variety of offenses, real and imagined. In many respects, the provisions of the Dodd-Frank law were designed to chastise banks and other companies for perceived wrong doing, especially abuses of consumers.

How will the Administration of Donald Trump deal with this legacy and the broader questions of financial regulation? How does regulation rank on the larger list of priorities that includes tax reform, trade, health care and immigration, to name but a few major policy areas.

\section{Trump Changes the Narrative}

Perhaps the biggest change for all financial services companies and professionals in 2017 is that the political narrative regarding financial regulation has shifted from a punitive, anti-business focus to a more traditionally conservative agenda focused on growth and jobs.

An important point to make regarding the regulatory response to the 2008 crisis is that liquidity, not a lack of capital, was the proximate cause of the catastrophe. Yet since 2008, regulators and policy makers have focused on increased capital for banks and limitations of risk taking as a general panacea for preventing a future crisis.

Any changes to the current regulatory system need to deemphasize the mechanistic use of capital as a catch all response to the financial crisis and instead construct policies to prevent the reoccurrence of acts of financial fraud, particularly the use of hidden leverage to enhance shortterm financial returns.

\footnotetext{
${ }^{1}$ Whalen, Richard Christopher, The Subprime Crisis: Cause, Effect and Consequences (March 1, 2008). Networks Financial Institute Policy Brief No. 2008-PB-04. Available at SSRN: https://ssrn.com/abstract=1113888
} 
It is self-evident that, throughout history, financial fraud perpetrated by hiding the true risks in the marketplace often has been the underlying cause of serious market disruptions. ${ }^{2}$ When deception is used to conceal risk the eventual revelation of that risk causes investors to react with surprise and fear, and rush for the exit. Systemic risk is when markets are caught unawares, as in the case of the BREXIT vote in the United Kingdom and the failure of Lehman Brothers in 2008. When a systemic event occurs, the cost of credit intermediation (CCI) increases dramatically, decreasing market liquidity and the effective leverage in the global economy.

The 2008 failures and government bailouts for Citigroup, American International Group, Fannie Mae and Freddie Mac, resulted not from a lack of capital, but rather from a sudden change in confidence regarding these institutions. These rescues caused enormous anger amongst the public, rage that was whipped into a fever pitch by the home foreclosure crisis that dragged on for nearly seven years. Politicians at the state and local level used the rubric of "consumer protection" as an excuse to extract billions of dollars from the shareholders of public and private companies via fines and other expenses related to remediation of alleged violations of law. Meanwhile, virtually no executives of the major US banks and financial institutions were subject to legal sanctions for acts of financial fraud and malfeasance. Instead the victims of the 2008 crisis - namely the shareholders of the largest financial institutions - have been repeatedly punished via fines and lopsided legal settlements.

The fact that the Bush and Obama Administrations were unwilling to prosecute the officers and directors of large, bad banks involved in obvious acts of fraud has set a troubling standard for public policy. In particular, the determination by the Obama Department of Justice that regardless of what laws they broke, the big banks were too integral to the global economic system to prosecute criminally has generated waves of public resentment against banks and bankers alike that arguably affected the results of the 2016 election in the US. Jed S. Rakoff, a U.S. District Judge in the Southern District of New York, in an essay on the financial crisis, noted:

"If...the Great Recession was in material part the product of intentional fraud, the failure to prosecute those responsible must be judged one of the more egregious failures of the criminal justice system in many years. Indeed, it would stand in striking contrast to the increased success that federal prosecutors have had over the past fifty years or so in bringing to justice even the highest-level figures who orchestrated mammoth frauds." ${ }^{3}$

The Financial Crisis Inquiry Commission (FCIC) 2014 report details numerous acts of fraud and chides the Fed and other regulators for failing "to ensure the safety and soundness of the nation's banking and financial system and to protect the credit rights of consumers." The FCIC noted correctly that protecting consumers is not solely about avoiding abuses in the lending process, but also enforcing the laws against fraud in the financials markets.

Confirming the view that fraud and a lack of transparency caused the crisis, the FCIC report notes that "Panic fanned by a lack of transparency of the balance sheets of major financial institutions,

\footnotetext{
${ }^{2}$ Feldkamp, Frederick L. and Whalen, R. Christopher, "Financial Stability: Fraud, Confidence and the Wealth of Nations," John Wiley \& Sons (2014).

${ }^{3}$ Rakoff, Jed S. "The Financial Crisis: Why Have No High-Level Executives Been Prosecuted?", The New York Review of Books, January 9, 2014
} 
coupled with a tangle of interconnections among institutions perceived to be 'too big to fail,' caused the credit markets to seize up." Yet none of the officers and directors of the major banks and financial institutions that failed in 2008 were prosecuted. The managers and owners of small banks and non-banks are subject to the full force of the law, but the officers and directors of the largest institutions are essentially given a free pass. ${ }^{4}$

With the change in government in Washington, the focus on punishment focused on the shareholders of financial institutions will gradually change to a more even-handed approach that will be reflected at all levels, from agency heads to examiners working in the field. The prosecutorial mindset of the Consumer Finance Protection Bureau (CFPB), to cite one leading example, is likely to change into a more sensible approach that tries to balance public policy objectives with fairness. Since the passage of Dodd-Frank, the CFPB has departed from past practice of issuing rules and instead regulates via lawsuits and enforcement actions, generating enormous anger from the various constituencies in the housing and other sectors.

\section{Likely Areas of Legislation}

The issues that are politically attractive to the new president are also the most difficult in terms of the amount of heavy lifting needed to make actual legislation a reality. For this reason, many veteran observers of Washington believe that President Trump will be able to get only one major piece of legislation through Congress in the first year of this term. Thus, choosing proposals that are relatively less problematic in a practical sense will increase the chances of success.

The Economy \& Taxes: Probably the first area of focus of the new Trump Administration, at least in a perfect world, would be taxes and spending, with both issues presented as parts of an economic stimulus program. But as Trump's election illustrates, voters understand that Washington is not perfect. The GOP controlled Congress will be supportive of a pro-growth agenda, but its members will also want to get a piece of pork barrel for the folks back home, making reaching any agreement a complex and lengthy exercise. Also, the Democrats in both the House and Senate will move as slowly as possible on any legislative proposals, mimicking the behavior of Republicans under President Barack Obama. Any tax and spending legislation, as a result, will require a huge amount of time and negotiation. Thus a major tax overhaul is the least likely choice-at least in the first year.

Health Care Reform: Probably the second agenda item for the Trump administration will be the Affordable Care Act (ACA), which has had a dismal record since enactment and is clearly a major pain point for small- and medium-sized businesses - part of the core political constituency for Trump. In many respects, dealing with the repeal of the ACA is the most attractive alternative politically, but like tax reform it also requires a great deal of heavy lifting.

Despite the statements by the president-elect about repealing ACA, the details involved will require a replacement, not merely a reversal. There are currently millions of Americans enrolled in heath insurance via the ACA, thus simply abolishing the law is not a practical course. As one key House GOP staffer opined, "you cannot simply repeal the ACA and go back to the status quo

\footnotetext{
${ }^{4}$ Morgenson, Gretchen \& Story, Louis, “In Financial Crisis, No Prosecution of Top Figures,” The New York Times, April 14, 2011
} 
ante." Despite the political attractiveness, fixing the ACA likely will be a medium-term project for the new president.

Financial Regulation: A third area of potential policy change is the regulatory environment, but changing the narrative regarding Dodd-Frank and related regulations is not a simple task. That said, addressing Dodd-Frank and related issues is a lot simpler than either tax reform or fixing the ACA. One idea floated by sources close to the Trump inner circle is passing a modified version of the Financial CHOICE Act, which is the project of House Financial Services Committee Chairman Jeb Hensarling, R-TX and has been subject to extensive hearings. Reuters notes:

"High on the list of probable targets is the Consumer Financial Protection Bureau. While Trump has not made any direct threats against the agency, he has said he would like to "dismantle" the Dodd-Frank Wall Street Reform and Consumer Protection Act, which created the bureau. His team has indicated support for the Financial Choice Act, legislation proposed this past summer that would offer banks an 'off-ramp' from the Dodd-Frank regime and break off various pieces of the financial legislation." 5

For those not familiar, the Financial CHOICE Act allows well-capitalized regional and community banks to opt out of much of the enhanced Dodd-Frank regulatory requirements, modifies the resolution authority in Dodd Frank, repeals the Volcker Rule and the Durbin Amendment, repeals the Financial Stability Oversight Council's SIFI Designation Authority and eliminates the Office of Financial Research, among other provisions. A summary of some of the bill's more significant provisions follows below.

- $\quad$ The Dodd-Frank Off-Ramp: This provision enhances U.S. financial market resiliency and promotes economic growth by offering well-managed, well-capitalized financial institutions - those with a simple leverage ratio of 10 percent - an "off ramp" from Dodd Frank's suffocating regulatory rules. In essence, if you have a least 10 percent capital, your bank can avoid many of the most onerous aspects of the Dodd-Frank law. In practical terms, this provision would be most helpful to regional and community banks.

- Bankruptcy Not Bailouts: This provision ends the discretion given to the FDIC with respect to the resolution of large banks. Bailouts are currently allowed by Dodd-Frank. This legislation establishes a new chapter in bankruptcy code that preserves the rule of law while enabling large, complex financial institutions to fail safely without making taxpayers foot the bill. Instead of the FDIC being able to save the failed institution, the bank's parent company would be forced to file bankruptcy and restructure, albeit with the acquiescence of federal regulators. It is important to note that the practical reality is that any depository which becomes insolvent still would be subject to seizure and resolution by the FDIC.

- $\quad$ Repeal of the Financial Stability Oversight Council's SIFI Designation Authority: Under Dodd-Frank, large banks are automatically considered to be "systemically important financial institutions." However, the Financial Stability Oversight Council (FSOC) also

\footnotetext{
${ }^{5}$ Rodriguez, Natalie, “Rolling Back Regulation In The Age Of Trump,” Law 360, January 19, 2017
} 
has the authority to designate non-banks as SIFIS as well, as it did in 2014 with respect to MetLife.

- On December 18, 2014, MetLife was notified by the FSOC that it had been designated a non-bank systemically important financial institution (SIFI). MetLife challenged that decision in federal court and on March 30, 2016 U.S. District Court Judge Rosemary Collyer ruled in MetLife's favor and rescinded FSOC's designation of the company as a Systemically Important Financial Institution. The Department of Justice on behalf of FSOC has appealed that decision and the case is now under consideration with the U.S. Court of Appeals for the DC Circuit. ${ }^{6}$

$\circ$ The decision in the MetLife case illustrates the arbitrary nature of the FSOC authority. The Court said: "The Financial Stability Oversight Council (FSOC) has determined that "material financial distress" at MetLife, Inc. could "pose a threat to the financial stability of the United States." The quoted phrases come from the Dodd-Frank Act, 12 U.S.C. $§ 5323(a)(1)$, and were defined by FSOC in formal guidance issued years before MetLife's designation. During the designation process, two of FSOC's definitions were ignored or, at least, abandoned. Although an agency can change its statutory interpretation when it explains why, FSOC insists that it changed nothing. But clearly it did so. FSOC reversed itself on whether MetLife's vulnerability to financial distress would be considered and on what it means to threaten the financial stability of the United States. FSOC also focused exclusively on the presumed benefits of its designation and ignored the attendant costs, which is itself unreasonable under the teachings of Michigan v. Environmental Protection Agency, 135 S. Ct. 2699 (2015). While MetLife advances many other arguments against its designation, FSOC's unacknowledged departure from its guidance and express refusal to consider cost require the Court to rescind the Final Determination." 7

O By repealing the FSOC's designation authority for "SIFIs" the act addresses one of Dodd-Frank's greatest sources of regulatory overreach, and eliminates the government's authority to anoint large financial institutions as "too big to fail." Rather than mitigating risks to financial stability, the FSOC's authority to designate non-bank financial institutions such as insurance companies and funds for "heightened prudential supervision" arguably undermines both financial stability and market discipline by signaling to market participants that the government considers the designated firm "too big to fail."

- $\quad$ Reform the Consumer Financial Protection Bureau: The CFPB's rules and policies rules and policies exemplify a punitive "Washington-knows-best" attitude that limits the availability of useful - and safe - products and services for consumers. The CHOICE Act will increase accountability by changing the Bureau's governance and funding mechanism to a commission structure subject to congressional appropriations. The CFPB has been

\footnotetext{
${ }^{6}$ Tracy, Ryan, "MetLife Asks Appeals Court to Uphold Removal of 'SIFI' Label," The Wall Street Journal, August 16,2016

${ }^{7}$ METLIFE V. FINANCIAL STABILITY OVERSIGHT COUNCIL, (MARCH 16, 2016)
} 
especially harmful to the mortgage industry and has caused the cost of servicing a mortgage to rise several fold since 2008. But the Bureau has suffered some significant legal setbacks in the past year.

- PHH, a large nonbank mortgage lender, made national headlines when it challenged CFPB Director Richard Cordray's \$103 million increase to a \$6 million fine initially levied against PHH for allegedly illegally referring consumers to mortgage insurers in exchange for kickbacks. The United States Court of Appeals for the District of Columbia Circuit ruled for PHH, declaring the CFPB's unitary leadership structure unconstitutional and vacating a $\$ 103$ million fine against $\mathrm{PHH}^{8}$

- Relief from Regulatory Burden for Community Financial Institutions: In the wake of the 2008 financial crisis, regulators have discouraged banks from making risky loans to either consumers or businesses. The bottom third of the population of US consumers, for example, are essentially unable to get a mortgage loan.

- The Financial CHOICE Act includes a host of reforms to address the plight of consumers finding it increasingly difficult to access affordable credit and community financial institutions unable to offer the products and services that those consumers demand. The goal is to free community financial institutions from unnecessarily burdensome regulations so that they can offer customers the personalized level of service that is the hallmark of the relationship-based lending model. Among other reforms, the plan requires financial regulatory agencies to appropriately tailor regulations to fit an institution's business model and risk profile, thereby reducing dead-weight compliance costs and allowing banks to devote more of their operating budgets to meeting customer needs.

- Federal Reserve Reform: The Financial CHOICE Act scales back the Fed's regulatory and supervisory powers and subjects them to greater congressional oversight and accountability. By promoting a more predictable, rules-based monetary policy, the Financial CHOICE Act provides a stronger foundation for economic growth than the Fed's improvisational approach of recent years under Fed Chair Janet Yellen. The legislation also calls for an audit of the Fed by the General Accountability Office and makes major changes to the Dodd-Frank provisions calling for "living wills" and annual bank stress tests.

- Upholding Article I: Reining in the Administrative State: The Financial CHOICE Act imposes a statutory cost-benefit analysis requirement on financial regulators. The legislation imposes the REINS Act, which requires Congress to pass, and the President to sign, a joint resolution of approval for all major regulations before they are effective. The Financial CHOICE Act will increase regulatory transparency and accountability in the rulemaking process by putting in place cost-benefit analysis requirements for all financial regulators. In addition, within five years of a new rule's implementation, the regulator

${ }^{8}$ PHH CORPORATION, ET AL.,. v. CONSUMER FINANCIAL PROTECTION BUREAU (October 11, 2016) 
must also complete an analysis that examines the economic impact of the rule, including its direct and indirect costs. The legislation converts agencies with single directors such as the CFPB to a commission structure and subjects all agencies to the Congressional appropriations process, eviscerating one of the key aspects of the Dodd-Frank law used by Democrats to insulate these agencies from public accountability.

- $\quad$ Amend Dodd-Frank Title IV: Title IV of the Dodd-Frank Act requires the SEC to expend scarce resources on the protection of sophisticated institutional investors and wealthy individual investors that would be better utilized protecting the millions of retail investors of more modest means who have a far greater need for the SEC's assistance.

- The Financial CHOICE Act amends Title IV of the Dodd-Frank Act to enhance funding opportunities for start-up companies and other job creators and to focus government resources on protecting mom-and-pop investors instead of the wealthiest Americans. The legislation also increases the SEC's legal authority to bring both civil and criminal actions for securities fraud.

- Repeal the Volcker Rule: Section 619 of the Dodd-Frank Act - popularly known as the "Volcker Rule" after its chief proponent, former Federal Reserve Chairman Paul Volcker-prohibits U.S. bank holding companies and their affiliates from engaging in "proprietary trading" and from sponsoring hedge funds and private equity funds. The real purposes of the Volcker Rule, however, is to address self dealing and conflicts of interests at banks between customers and the bank.

O The Volcker Rule should be left in place. One proposal would allow the brokerdealer affiliates of banks to trade for their own account while the depository remains under the restrictions of the Volcker Rule today.

- $\quad$ Repeal the Durbin Amendment: During the Senate's consideration of financial regulatory reform legislation, Senator Richard Durbin (D-IL) offered an amendment to cap interchange fees on debit card transactions.300 Senator Durbin's amendment passed by a vote of 64-33 and ultimately became Section 1075 of the Dodd-Frank Act.301 The amendment was not even considered by the House prior to final passage of the Dodd-Frank Act, and was never the subject of a hearing in the House Financial Services Committee. The Financial CHOICE Act would repeal the Durbin Amendment.

- Eliminate the Office of Financial Research: Title I of the Dodd-Frank Act created the Office of Financial Research (OFR) within the Treasury Department to support the work of the FSOC, by collecting and analyzing data on systemic risk in financial markets.325 The OFR is headed by an independent director who is appointed by the President to serve a six-year term, subject to the advice and consent of the Senate.326 Dodd-Frank gives the Director "sole discretion" for determining how to carry out his Dodd-Frank authorities. To date, the OFR has produced little public research of value to either the regulatory community or the public. The Financial CHOICE Act would eliminate the OFR. 
- SEC Enforcement Issues: Because both Wall Street and Washington must be held accountable if future financial melt-downs are to be averted, the Financial CHOICE Act increases penalties for violations of the securities laws for individuals and entities, but couples those increases with important reforms to the SEC's enforcement program designed to promote the rule of law and ensure due process. As noted above, the Financial CHOICE Act significantly increases the SEC's civil penalty authority, as well as criminal sanctions under the federal securities laws, for the most serious offenses. It increases the first and second tier penalties, and nearly doubles the penalty amounts for third-tier offenses - those involving substantial losses for the victim or substantial pecuniary gain for the offender - for both individuals and corporations.

- Improving Insurance Regulation by Reforming Dodd-Frank Title V: The Dodd-Frank Act made two notable changes to the role the federal government plays in the insurance industry. First, in Title V, the Dodd-Frank Act created a new Federal Insurance Office (FIO) within the Treasury Department to provide the federal government with information and expertise on insurance matters. Though by design FIO has no supervisory or regulatory authority, the Dodd-Frank Act charges the FIO with several mandates, including:

- monitoring all aspects of the insurance industry;

- recommending which insurance companies be designated for heightened prudential standards and supervision;

- assisting in administering the Terrorism Risk Insurance Program;

- coordinating federal involvement and policymaking on international insurance matters and in negotiations of international insurance agreements; and

- consulting with state insurance regulators on matters of national or international importance.435 The Dodd-Frank Act also charged the FIO Director with producing several one-time and annual reports on matters relating to the insurance industry.

\section{Conclusion}

Some or all of the provisions of the Financial CHOICE Act could eventually become law. A modified version of legislation could be made palatable to both parties in the Senate and, despite Democratic opposition, could become law far more easily than either a tax reform bill or ACA reform. Rep. Hensarling is close to Vice President Mike Pence from the latter's days in Congress. Hensarling even travelled with the Trump campaign, thus the provisions of the Financial CHOICE Act are familiar to the new administration. There are a number of other issues that may catch the attention of the new President next year, but an amended version of the Financial CHOICE Act has the highest probability of success in 2017. Needless to say, the financial services industry including banks, insurers and nonbank financial institutions will be very supportive of passage of some form of the Financial CHOICE Act. 